\title{
Obstetric violence in the perception of puerperal women
}

\begin{abstract}
This article aims to analyze the perception of puerperal women regarding obstetric violence in a maternity hospital in a municipality in Paraíba. It is a descriptive field study with a quantitative approach. The study sample consisted of 132 women. Data collection was carried out in February 2019. The data were analyzed and presented in tables, tabulated, and analyzed in the statistical package Statistical Package for the Social Sciences, version 21, all of which were discussed in the light of the relevant literature. and other works published in the area. Amid questions about obstetric violence, 79 (59.8\%) reported not knowing the term "obstetric violence"; 126 (95.5\%) mothers stated that they did not receive information about obstetric violence during prenatal care, when questioned, $121(91.7 \%)$ of these did not report any episode. Among the participants, $97(73.5 \%)$ said that they think the use of oxytocin is a type of violence; episiotomy was considered by 48 (36.4\%) of women as a type of obstetric violence. The data warns that the lack of information in prenatal care by the nursing staff can lead to greater consequences such as obstetric violence.
\end{abstract}

Keywords: Obstetric Nursing; Puerperium; Violence Against Women; Women's Health.

RESUMEN | Este artículo tiene como objetivo analizar la percepción de las mujeres puerperales con respecto a la violencia obstétrica en un hospital de maternidad en un municipio de Paraíba. Es un estudio de campo descriptivo con un enfoque cuantitativo. La muestra del estudio consistió en 132 mujeres. La recolección de datos se realizó en febrero de 2019. Los datos se analizaron y presentaron en tablas, tabuladas y analizadas en el paquete estadístico Paquete estadístico para las ciencias sociales, versión 21, todo lo cual se discutió a la luz de la literatura relevante. y otros trabajos publicados en el área. En medio de preguntas sobre violencia obstétrica, $79(59.8 \%)$ informaron no conocer el término "violencia obstétrica"; 126 (95.5\%) madres declararon que no recibieron información sobre violencia obstétrica durante la atención prenatal, cuando se les preguntó, 121 (91.7\%) de estas no informaron ningún episodio. Entre los participantes, 97 (73.5\%) dijeron que piensan que el uso de oxitocina es un tipo de violencia; La episiotomía fue considerada por $48(36,4 \%)$ de las mujeres como un tipo de violencia obstétrica. Los datos advierten que la falta de información en la atención prenatal por parte del personal de enfermería puede tener mayores consecuencias, como la violencia obstétrica.

Palavras claves: Enfermería Obstétrica; Puerperio; Violencia contra las Mujeres; Salud de la Mujer.

RESUMO | Este artigo objetiva analisar a percepção de puérperas a respeito da violência obstétrica em uma maternidade de um município paraibano. Trata-se de um estudo de campo, descritivo, com abordagem quantitativa. A amostra do estudo foi composta por 132 mulheres. A coleta de dados foi realizada no mês de fevereiro de 2019. Os dados foram analisados e apresentados em forma de tabelas, tabulados e analisados no pacote estatístico Statistical Package for the Social Sciences, versão 21, sendo todos discutidos à luz da literatura pertinente ao tema e outros trabalhos publicados na área. Em meio aos questionamentos quanto á violência obstétrica, 79 (59,8\%) relataram não conhecer o termo "violência obstétrica"; 126 (95,5\%) puérperas expuseram que não receberam informações sobre violência obstétrica no acompanhamento do pré-natal, quando questionadas, $121(91,7 \%)$ dessas não narraram nenhum episódio. Dentre as participantes $97(73,5 \%)$ pronunciaram que acham que o uso de ocitocina é um tipo de violência; a episiotomia foi considerada por $48(36,4 \%)$ das mulheres como um tipo de violência obstétrica. Os dados alertam que a falta de informações no pré-natal pela equipe de enfermagem pode levar a consequências maiores como a violência obstétrica.

Palavras-chaves: Enfermagem Obstétrica; Puerpério; Violência Contra a Mulher; Saúde da Mulher.

\section{Karem Cristinny Fontes Pascoal}

Graduating in Nurse. University Center of João Pessoa, UNIPÊ, Brazil.

\section{Michelle Alves de Carvalho}

Master's in Nursing from the Graduate Nursing Program (PPGENF) at UFPB.

\section{Rozileide Martins Simões Candeia}

Specialist in Family Health at Integrated Faculty of Patos - FIP.

\section{Jéssica Barreto Pereira}

Nurse. Master's in Nursing from the Graduate Nursing Program (PPGENF) at UFPB.

\section{Ronny Anderson de Oliveira Cruz}

Master's in Nursing from the Graduate Nursing Program (PPGENF) at UFPB.

\section{Thaynara Ferreira Filgueiras}

Nurse. Master's in Nursing from the Graduate Nursing Program (PPGENF) at UFPB.

Received on: 05/06/2020

Approved on: 05/07/2020
INTRODUCTION

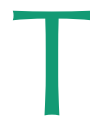

-he World Health Organization (WHO) defines as violence the purposeful use of physical force or possession, legitimate or in intimidation, against oneself, against another individual, or against a population or a group of people, which derives or has high probability of proceeding in damage, death, psychological damage or inability to develop. Thus, the definition used by the $\mathrm{WHO}$ on the concept of violence is linked to the conscience of intentionally committing a violent act, causing physical and psychological damage to others ${ }^{(1,2)}$.

Nesse contexto, a Violência Obstétrica (VO) é compreendida como atos 
realizados por profissionais da saúde em relação ao corpo e aos processos reprodutivos, podendo ocorrer também ao longo do processo de trabalho de parto, parto e puerpério. Esse tipo de violência ocorre através do excesso de intervenções e medicalizações excessivas e patologizando um processo natural ${ }^{(3)}$.

Among the practices that characterize VO, we can mention: the performance of cesarean section or episiotomy in the patient, without consent; prohibition on being accompanied by a person of your choice; subject it to unnecessary, painful or humiliating procedures, such as intestinal lavage, repetitive touch examination by different professionals, to impose that vaginal delivery be in a gynecological position; administer uterotonics to accelerate the delivery process; to treat the pregnant woman, parturient, puerperal or in a situation of abortion in an aggressive, humiliating, disrespectful, mocking manner, or in a threatening manner, so that she feels embarrassed or inferior, specifies the Ley Orgánica on the Derecho de las Mujeres a una Vida Libre de Violencia, updated in $2014^{(4)}$.

The study can offer nurses information that can contribute to raising awareness of the humanization of monitoring labor, delivery, and the puerperium. It is worth mentioning that the data will be used in the production of research and in the transmission of knowledge, which will be available without restrictions on access by researchers, or any other citizen.

Violence in assisting the birth process is a serious problem for women's health. It is evident that $25 \%$ of Brazilian women have already suffered some type of violence during their labor, delivery and puerperium $^{(5)}$. In this sense, as a participant in the extension project "Gerar Vidas", it was possible to hear reports of puerperal women after the experience of childbirth and, from that point on, the interest arose to deepen the knowledge on this topic, as they believe in the extreme importance that has for nursing care, especially for obstetric nursing.
In view of the above, this study aimed to analyze the perception of puerperal women regarding obstetric violence in a maternity hospital in a municipality in Paraíba.

\section{METHODOLOGY}

This research was carried out in the rooming-in sector of a low-risk maternity hospital located in a municipality in Paraíba. This municipality has a public maternity hospital that attends, in addition to its resident population in a pregnant-puerperal state, women from the surrounding cities, in the service are assisted on average of 04 deliveries/day. It is noteworthy that in 2017 the institution assisted 1,567 vaginal deliveries and 1,241 surgical deliveries.

The study population was composed of all the puerperal women who were hospitalized in the referred maternity room. For the selection of the sample, the following inclusion criteria were considered: being a puerperal woman, who was hospitalized in the maternity ward and aged over 18 years.

Postpartum women who did not meet one or more of the inclusion criteria or who refused to participate in the research were excluded from the sample.

The sample consisted of an average of at least $25 \%$ of the population that met the inclusion criteria, totaling 132 women.

The collection instrument consisted of a semi-structured questionnaire script, prepared by the researcher, composed of two parts: the first deals with the sociodemographic profile of the mothers; the second consists of an analysis of the gynecological-obstetric profile with questions around the objectives of the study.

The project was registered at Plataforma Brasil and data collection was carried out soon after the consent of the service that was the field of this study and the project's approval by the Research Ethics Committee of Centro Universitário de João Pessoa, CAAE: 04401018.5.0000.5176, for data collection from hospitalized mo- 
Table 1. Characterization of study participants. João Pessoa, PB, Brazil, 2019.

Variáveis

n

$\%$

Idade

18 a 29 anos

30 anos ou mais

85

47

64,6

Estado Conjugal

\begin{tabular}{|lcc|}
\hline Solteiro & 27 & 20,5 \\
\hline Casado & 37 & 28,0 \\
\hline União estável & 66 & 50,0 \\
\hline Divorciado & 1 & 8,0 \\
\hline Viúvo & 1 & 8,0
\end{tabular}

Escolaridade

\begin{tabular}{|lcc|}
\hline Até 3 anos & 5 & 3,8 \\
\hline 4 a 7 anos & 37 & 28,0 \\
\hline Acima de 7 anos & 89 & 67,4 \\
\hline Nível superior & 1 & 8,0 \\
\hline Ocupação & & \\
\hline Doméstica & 79 & 59,8 \\
\hline Estudante & 10 & 7,6 \\
\hline Agricultora & 21 & 15,9 \\
\hline Outros & 22 & 16,7
\end{tabular}

Table 2. Obstetric data of the study participants. João Pessoa, PB, Brazil, 2019

\section{Variáveis}

n

Gestação

\begin{tabular}{|lll|}
\hline Primigesta & 35 & 26,5 \\
\hline Secundigesta & 45 & 34,1 \\
\hline Multigesta & 52 & 39,4 \\
\hline Partos & & \\
\hline Primipara & 41 & 31,1 \\
\hline Multipara & 91 & 68,9 \\
\hline
\end{tabular}

Vaginal

\begin{tabular}{lcc} 
Sim & 97 & 73,0 \\
\hline Não & 35 & 26,5 \\
\hline Abdominal & 32 & 24,2 \\
\hline Sim & & \\
\hline Não & 100 & 75,8 \\
\hline Gravidez desejada & 81 & 61,4 \\
\hline Sim & 51 & 38,6 \\
\hline Não & & \\
\hline Gravidez planejada & 58 & 43,9 \\
\hline Sim & &
\end{tabular}

thers, which began in February and ended in April 2019.

Initially, a brief explanation of the research objectives was made to the research participants to achieve greater acceptance in the study participation. Once they were willing to contribute to the study, the participant signed the Free and Informed Consent Form and the questionnaires were applied. The data were collected and recorded by the researcher herself, and the questions were recorded on the form itself, allowing greater interaction with the participants.

After the end of the collection, the data were analyzed using simple descriptive statistics (frequency and percentage) and measures of central tendency (average or median according to need). The data were presented in the form of graphs and tables, tabulated and analyzed in the statistical package Statistical Package for the Social Sciences ${ }^{\circledR}$ (SPSS), version 21, all of which are discussed in the light of the relevant literature and other works published in the area.

\section{RESULTS}

The tables below present the information obtained by the field research: Table 1 shows the socio-demographic data of the research such as age, marital status, education and occupation; Tables 2, 3 and 4, on the other hand, give us the questionnaire obstetric data that were addressed in the questionnaire..

According to the results obtained, it was found that among the study participants all were puerperal, 85 (64.4\%) were aged between 18 and 29 years. Of these women, $66(50 \%)$ are in a stable relationship, 37 (28\%) were married, 27 $(20.5 \%)$ were single and $1(0.8 \%)$ was widowed or divorced. Only one $(8 \%)$ had a college degree, $89(67.4 \%)$ had an education above the 7 th grade, $37(28 \%)$ had a 4 th to 7 th grade and $5(3.8 \%)$ up to the 3 rd grade. Among the puerperal women, $79(59.8 \%)$ were domestic workers, $10(7.6 \%)$ students, 21 (15.9\%) 


\begin{tabular}{|c|c|c|}
\hline Não & 74 & 56,1 \\
\hline \multicolumn{3}{|c|}{ Número de consultas pré-natal } \\
\hline$<6$ consultas & 27 & 20,5 \\
\hline$>6$ consultas & 95 & 72,0 \\
\hline Ignorado & 10 & 7,6 \\
\hline \multicolumn{3}{|c|}{ Mês que iniciou o pré-natal } \\
\hline Precoce & 88 & 66,7 \\
\hline Tardio & 28 & 21,1 \\
\hline Ignorado & 16 & 12,1 \\
\hline \multicolumn{3}{|c|}{ Table 3. Obstetric data of the study participants. João Pessoa, PB, Brazil, 2019} \\
\hline Variáveis & $\mathrm{n}$ & $\%$ \\
\hline \multicolumn{3}{|c|}{$\begin{array}{l}\text { Você sofreu algum tipo de violência durante o } \\
\text { trabalho de parto/parto e ou puerpério? }\end{array}$} \\
\hline Sim & 11 & 8,3 \\
\hline Não & 121 & 91,7 \\
\hline \multicolumn{3}{|c|}{$\begin{array}{l}\text { Você considera o uso de ocitocina um tipo de } \\
\text { violência obstétrica? }\end{array}$} \\
\hline Sim & 35 & 26,5 \\
\hline Não & 97 & 73,5 \\
\hline \multicolumn{3}{|c|}{$\begin{array}{l}\text { Você considera a Episiotomia um tipo de } \\
\text { violência obstétrica? }\end{array}$} \\
\hline Sim & 48 & 36,4 \\
\hline Não & 84 & 63,6 \\
\hline \multicolumn{3}{|c|}{$\begin{array}{l}\text { Durante o trabalho de parto foi incentivado a in- } \\
\text { gesta de liquidos e o consumo de comidas leves? }\end{array}$} \\
\hline Sim & 57 & 43,2 \\
\hline Não & 47 & 35,6 \\
\hline Não se aplica & 28 & 21,2 \\
\hline \multicolumn{3}{|c|}{$\begin{array}{l}\text { Foi realizada alguma conduta de alivio de dor du- } \\
\text { rante o acompanhamento do trabalho de parto? }\end{array}$} \\
\hline Sim & 58 & 43,9 \\
\hline Não & 74 & 56,1 \\
\hline \multicolumn{3}{|c|}{$\begin{array}{l}\text { Realizaram algum procedimento sem o seu } \\
\text { consentimento durante o seu parto? }\end{array}$} \\
\hline Sim & 3 & 2,3 \\
\hline Não & 129 & 97,7 \\
\hline \multicolumn{3}{|c|}{$\begin{array}{l}\text { Foi realizado algum tipo de agressão verbal } \\
\text { com você durante o parto? }\end{array}$} \\
\hline Sim & 6 & 4,5 \\
\hline Não & 126 & 95,5 \\
\hline
\end{tabular}

Você foi impedida de amamentar seu filho na

hora que desejou?

farmers and $22(16.7 \%)$ corresponded to other occupations.

As for obstetric data, 52 (39.4\%) were multigravid, that is, they have already had three or more children, 45 (34.1\%) were pregnant and 35 (26.5\%) were pregnant. Regarding parity, we observed that $91(68.9 \%)$ were multiparous and 40 (31.1\%) were primiparous. Among the interviewees, 97 (73.5\%) gave birth by vaginal delivery and 32 (24.2\%) corresponded to abdominal deliveries. When asked about pregnancy planning, 81 (61.4\%) of women reported that pregnancy was desired and 58 (43.9\%) planned. In the variable prenatal consultations, 95 (72\%) had more than six consultations in the prenatal period.

Regarding the presence of the companion, 118 (88.4\%) women were instructed about the accompaniment during labor, delivery, and the puerperium.

Amid questions about VO, 53 (40.2\%) had already heard about it, 79 (59.8\%) reported not knowing the term "obstetric violence"; 126 (95.5\%) mothers stated that they did not receive information about VO during prenatal care. When asked about episodes of VO, 11 (8.3\%) of the mothers mentioned that they had already suffered, $121(91.7 \%)$ of them did not report any episode. Among the participants questioned, $97(73.5 \%)$ said that they think the use of oxytocin is a type of $\mathrm{VO}$ and 123 (93.2\%) of these women answered that they did not receive information about episiotomy in their prenatal care. Episiotomy was considered by 48 (36.4\%) of women as a type of VO and in higher percentages they considered it not, comprising 84 (63.6\%).

Among the interviewees, 57 (43.2\%) answered that they drank water and ate some kind of light food during their labor, $47(35.6 \%)$ answered that they did not, of the 132 women 58 (43.9\%) said who received pain relief measures during labor and the other 74 (56.1\%) said they did not. Of the interviewees, $129(97.7 \%)$ reported that no procedure was performed without their permission, 


\begin{tabular}{lcc|}
\hline Sim & 0 & 0 \\
\hline Não & 132 & 100 \\
\hline $\begin{array}{l}\text { Durante o acompanhamento do pré-natal foi } \\
\text { orientada a realização de um parto cirúrgico? }\end{array}$ & \\
\hline Sim & 42 & 31,8 \\
\hline Não & 90 & 68,2 \\
\hline $\begin{array}{l}\text { Você já vivenciou em partos anteriores algum } \\
\text { tipo de violência obstétrica? }\end{array}$ & \\
\hline Sim & 16 & 12,1 \\
\hline Não & 116 & 87,9 \\
\hline
\end{tabular}

Table 4. Obstetric data of the study participants. João Pessoa, PB, Brazil, 2019

\begin{tabular}{lcc} 
Variáveis & n & $\%$ \\
$\begin{array}{l}\text { Conhecimento acerca da Lei } \mathbf{n} .{ }^{\circ} \mathbf{1 1 . 1 0 8} \text { (Lei do } \\
\text { acompanhante)? }\end{array}$ & \\
\hline Sim & 118 & 89,4 \\
\hline Não & 10 & 10,6 \\
\hline
\end{tabular}

Você já ouviu falar em violência obstétrica?

\begin{tabular}{|lcc|}
\hline Sim & 53 & 40,2 \\
\hline Não & 79 & 59,8 \\
\hline $\begin{array}{l}\text { Você recebeu informações sobre os tipos de violên- } \\
\text { cia obstétrica durante as consultas de pré-natal? }\end{array}$ & \\
\hline Sim & 6 & 4,5 \\
\hline Não & 126 & 95,5 \\
\hline
\end{tabular}

Recebeu informações sobre a episiotomia (caracterizada como violência obstétrica)?

\begin{tabular}{|lcc|} 
Sim & 9 & 6,8 \\
\hline Não & 123 & 93,2 \\
$\begin{array}{l}\text { Vantagens do parto via vaginal durante o seu } \\
\text { pré-natal? }\end{array}$ & \\
\hline Sim & 73 & 55,3 \\
\hline Não & 59 & 44,7 \\
\hline
\end{tabular}

while 126 (95.5\%) said that they did not DISCUSSION suffer any type of verbal aggression during childbirth.

The puerperal women participating in the study, in their entirety, responded that they were not prevented from breastfeeding their children at any time, including, they reported that they were always encouraged by the service professionals. Among these, 90 (68.2\%) said that they had not received any information about the way of delivery, its advantages, and disadvantages in their prenatal care. events due to the lack of information passed on.

In a study carried out in Goiás, Brazil, which showed results that concern the data of this research, all participants reached the minimum number of six prenatal consultations, as recommended by the Ministry of Health, however, despite the increased coverage of prenatal care was observed among the primiparous mothers of this study, the quality of care was not satisfactory among these pregnant women monitored at the service ${ }^{(6)}$.

Maintaining and improving maternal and child health are some of the objectives defined by the Ministry of Health and, for this, prenatal and puerperal care, whose responsibility is the Unified Health System (SUS), is essential. Within the scope of the Cegonha Network, care for women during pregnancy and postpartum advocates actions for prevention and health promotion, in addition to proper diagnosis and treatment of problems that occur during this period ${ }^{(7)}$.

The Ministry of Health emphasizes that prenatal care is a time when pregnant women should receive guidance in relation to the types of delivery, from technical aspects such as body work, which includes routines and procedures of reference maternity and aspects emotional and cognitive. For this, professionals involved in prenatal care must adopt educational measures ${ }^{(8)}$.

Estudo de campo sobre violência obstétrica realizado em uma maternidade de município paraibano mostrou que cerca de 121 mulheres relataram não ter sofrido nenhum tipo de violência durante o trabalho de parto, parto e pós parto, porém quando interrogadas sobre outros assuntos no decorrer da entrevista verbalizaram algumas condutas que são consideradas VO. A maioria das puérperas respondeu não saber o que é $\mathrm{VO}$, as que mencionaram saber sobre a temática afirmam que as informações foram obtidas através da Internet e televisão e que não foram re- 
passadas durante o acompanhamento das consultas de pré-natal.

Em relação ao uso de ocitocina, a maioria das puérperas respondeu que o seu uso não é um tipo de VO. De acordo com os estudos e evidências, a ocitocina, entre outras drogas, são consideradas uma associação ruim, e ao surgimento de efeitos indesejados graves, resultando em eventos perinatais adversos, devendo seu uso ser seletivo e restrito a situações que existem indicações ${ }^{(9)}$. The use of oxytocin to induce and conduct normal labor can bring benefits to the woman, if used judiciously, however, the indiscriminate use of this drug may cause harm to the mother and baby ${ }^{(10)}$.

The results of this research show that the majority of the interviewees did not know what episiotomy was and that it is considered a type of VO. Episiotomy is one of the procedures that women most complain about, because it is performed without having been previously informed or without their consent ${ }^{(11)}$. Since the 1980s, this inter- vention has been discussed by WHO as an evil when used routinely.

It is valid to reiterate that some practices considered bad at the time of delivery, such as episiotomy, were identified by the interviewees as something good, a report by one of the puerperal women was that in her previous delivery she had performed the cut and that it was less painful than in her last delivery.

\section{CONCLUSION}

In general, the assistance received by the mothers who participated in this study was marked by practices and manifestations of $\mathrm{VO}$, even though, in most cases, they are not reported and/ or identified by them. The ignorance of the theme, the lack of provision of basic information during the entire period of prenatal care, childbirth and postpartum, by health professionals and the consequences of such behaviors were decisive factors to understand that VO has occurred routinely.
The nurse in the care of labor has the role of welcoming and supporting the pregnant woman, monitoring her signs and symptoms, offering non-pharmacological methods of pain relief, providing humanized care to the pregnant woman and her companion.

Some limitations were found during data collection; however, they did not interfere in a satisfactory result. There were difficulties regarding the approach, because in addition to the information being collected from the bed of the joint accommodation among the other puerperal women, there was also resistance on the part of the puerperal women for fear that the information provided might harm them in some way.

Thus, it is believed to have achieved all the objectives of the study, since the data showed that the lack of information in prenatal care by health professionals can lead to greater consequences, such as the occurrence of obstetric violence.

\section{References}

1. Andrade BP, Aggio CM. Violência Obstétrica: a dor que cala. Anais do III Simpósio Gênero e Políticas Públicas [Internet]. Universidade Estadual de Londrina, 27 a 29 de maio de 2014 [acesso em 12 ago 2018]. Disponível em: http://www.uel.br/eventos/gpp/pages/arquivos/GT3_Briena\%20 Padilha\%20Andrade.pdf.

2. Pérez BAG, Oliveira EV, Lago MS. Percepções de puérperas vítimas de violência institucional durante o trabalho de parto e parto. Revista Enfermagem Contemporânea [Internet]. 2015 [acesso em 12 ago 2018]; 4(1):66-77.

Disponivel em: https://www5.bahiana.edu.br/index.php/enfermagem/ article/view/472/436.

3. Medeiros NCM, et al. Violência obstétrica: percepções acerca do parto normal. Revista Tema em Saúde [Internet]. 2016 [acesso em 12 ago 2018]; 16(3):503-528. Disponível em: http://temasemsaude.com/wp-content/uploads/2016/09/16331.pdf.

4. Carvalho AS, et al. Violência obstétrica: a ótica sobre os princípios bioéticas e direitos das mulheres. Revista da Escola de Enfermagem da USP [Internet]. 2019 [acesso em 01 mai 2019]; 26(1):52-58. Disponível em: https://www.mastereditora.com.br/periodico/20190306_114936.pdf.

5. Alves VBO. Percepções de puérperas acerca da violência obstétrica. [dissertação]. [Internet]. Programa de Pós-Graduação em Enfermagem da Faculdade de Enfermagem da Universidade Federal de Goiás, 2017 [acesso em 08 jun 2020]. Disponível em: https://repositorio.bc.ufg.br/ tede/bitstream/tede/7831/5/Diserta\%C3\%A7\%C3\%A30\%20-\%20Vitt $\%$ C3\%B3ria\%20Braz\%20de\%200liveira\%20Alves\%20-\%202017.pdf. 6. Nascimento JS. Assistência à Mulher no Pré-Natal, Parto e Nascimen- to: Contribuições da Rede Cegonha. Revista Port.: Saúde e Sociedade [Internet]. 2018 [acesso em 19 out 2018]; 3(1):694-709. Disponível em: http://www.seer.ufal.br/index.php/nuspfamed/article/view/4241/3717.

7. Tomasi $\mathrm{E}$, et al. Qualidade da atenção pré-natal na rede básica de saúde do Brasil: indicadores e desigualdades sociais. Caderno de Saúde Pública [Internet]. 2017 abr [acesso em 08 jun 2020]; 33(3). Disponível em: https://www.scielosp.org/article/csp/2017.v33n3/e00195815/\#.

8. Reis TLR, et al. Autonomia feminina no processo de parto e nascimento: revisão integrativa da literatura. Revista Gaúcha de Enfermagem [Internet]. 2017 [acesso em 19 out 2018]; 38(1). Disponível em: http://www.scielo.br/scielo.php?script=sci_arttext\&pi$\mathrm{d}=\mathrm{S} 1983-14472017000100503$ \&lang $=$ pt.

9. Domingues RQ. 0 uso da ocitocina exógena no trabalho de parto: uma revisão integrativa. [trabalho de conclusão de curso]. [Internet]. Curso de Especialização de Enfermagem Obstétrica da Escola de Enfermagem da Universidade Federal de Minas Gerais, 2016 [acesso em 01 mai 2019]. Disponível em: http://hdl.handle.net/10183/147954-2016. 10. Schincaglia CY, et al. As consequências do uso de ocitócitos durante o parto. Revista Cientifica de Enfermagem [Internet]. 2017 [acesso em 01 mai 2019]; 7(19):75-82. Disponível em: https://www.recien.com.br/ index.php/Recien/article/view/184/pdf_1

11. Rodrigues $F A C$, et al. Violência obstétrica no processo de parturição em maternidades vinculadas à Rede Cegonha. Reprodução e Climatério [Internet]. 2017 [acesso em 19 out 2018]; 32:78-84. Disponível em: http://www.repositorio.ufc.br/bitstream/riufc/23360/1/2017_art_facrodrigues.pdf. 